\title{
ANALISIS TITIK IMPAS USAHATANI TOMAT DI DESA SINDANGJAYA KECAMATAN MANGUNJAYA KABUPATEN PANGANDARAN
}

\section{BREAK EVEN POINT ANALYSIS OF TOMATO FARMING IN SINDANGJAYA VILLAGE, MANGUNJAYA DISTRICT, PANGANDARAN REGENCY}

\author{
DEVI OKTAVINA PUTRI*, MUHAMAD NURDIN YUSUF, \\ AGUS YUNIAWAN ISYANTO \\ Fakultas Pertanian, Universitas Galuh \\ *E-mail: devioktavina.p@gmail.com
}

\begin{abstract}
ABSTRAK
Penelitian dilaksanakan dengan tujuan untuk mengetahui titik impas (break even point, BEP) usahatani tomat di Desa Sindangjaya Kecamatan Mangunjaya Kabupaten Pangandaran. Penelitian dilaksanakan dengan menggunakan studi kasus pada kelompok tani Puncak Jaya. 21 anggota kelompok seluruhnya diambil sebagai sampel penelitian atau dilaksanakan sensus. Hasil penelitian menunjukkan BEP penerimaan Rp 965.888,82/ha/MT, BEP volume produksi 3.440,87 kg/ha, dan BEP harga $\mathrm{Rp} 826 / \mathrm{kg}$.
\end{abstract}

Kata Kunci: usahatani tomat, titik impas, penerimaan, volume produksi, harga

\section{ABSTRACT}

The research was conducted with the aim of knowing the break even point (BEP) of tomato farming in Sindangjaya Village, Mangunjaya District, Pangandaran Regency. The research was conducted using a case study in the Puncak Jaya farmer group. All 21 group members were taken as the research sample or carried out a census. The results showed that the BEP revenue Rp 965,888.82/ha, BEP for the production volume of $3,440.87 \mathrm{~kg} / \mathrm{ha}$, and BEP price $R p$ 826/kg.

Keywords: tomato farming, break even point, revenue, production volume, price

\section{PENDAHULUAN}

Tanaman hortikultura mempunyai kedudukan yang penting dalam kehidupan masyarakat sebagai sumber gizi, sedangkan dalam perekonomian mempunyai nilai ekonomis yang tinggi dilihat dari sumberdaya terhadap peningkatan devisa negara (Patricia dalam Talumingan, dkk., 2011). Salah satu komoditas hortikultura yang mempunyai nilai ekonomis tinggi adalah tomat.

Buah tomat penting sebagai komponen makanan karena mengandung lycopene yang berfungsi untuk menjaga tubuh dari serangan penyakit kanker dan penyakit degenerasi syaraf. Selain konsumsi segar, buah tomat juga dimanfaatkan untuk berbagai industri, misalnya sambal, saos, minuman, jamu, dan kosmetik (Srinivasan, 2010).

Data Badan Pusat Statistik Kabupaten Ciamis (2019) menunjukkan bahwa usahatani tomat dilaksanakan di Kecamatan Cigugur seluas 2 hektar, Kecamatan Parigi seluas 1 hektar, dan Kecamatan Mangunjaya seluas 37 hektar. 
Usahatani tomat di Kecamatan Mangunjaya dilaksanakan oleh petani yang tergabung dalam kelompok tani Puncak Jaya. Survey pendahuluan menunjukkan belum ada satu petani pun yang mengetahu titik impas dari usahatani yang dilaksanakannya. Menurut Sutarni dkk. (2016), analisis titik impas (break even point, BEP) digunakan untuk mengetahui batas nilai produksi dan volume produksi suatu usaha mencapai nilai impas yang artinya suatu usaha tersebut tidak mengalami keuntungan ataupun kerugian.

Berdasarkan uraian tersebut, maka penelitian ini dilaksanakan dengan tujuan mengetahui titik impas pada usahatani tomat di di Desa Sindangjaya Kecamatan Mangunjaya Kabupaten Pangandaran.

\section{METODE PENELITIAN}

Penelitian dilaksanakan dengan menggunakan studi kasus pada kelompok tani Puncak Jaya di Desa Sindangjaya Kecamatan Mangunjaya Kabupaten Pangandaran. Menurut Arikunto (2013), studi kasus merupakan penelitian secara intensif, terperinci, dan mendalam pada suatu subyek penelitian.

Data yang digunakan terdiri atas data primer dan sekunder. Anggota kelompok tani Puncak Jaya sebanyak 21 orang, dan seluruhnya diambil sebagai sampel penelitian atau dilaksanakan sensus. Menurut Sugiyono (2014), sensus adalah teknik penentuan sampel apabila semua populasi digunakan sebagai sampel.

BEP penerimaan merupakan BEP yang menunjukkan penerimaan minimal pada usahatani tomat agar tidak mengalami kerugian, dan dihitung dengan menggunakan rumus berikut (Saeri, 2011):

$$
\mathrm{BEP}_{\mathrm{np}}=\frac{\mathrm{FC}}{1-\frac{\mathrm{VC}}{\mathrm{TR}}}
$$

Keterangan:

BEPnp: BEP Penerimaan

TR : Total Revenue (Penerimaan total)

FC : Fixed Cost (Biaya Tetap)

VC : Variable Cost (Biaya Variabel)

BEP volume produksi dan harga dihitung dengan menggunakan rumus berikut (Efendi, 2016):

a. BEP Volume Produksi

BEP volume produksi merupakan BEP yang menunjukkan produksi minimal yang harus dicapai pada usahatani tomat agar tidak mengalami kerugian dengan rumus menurut Efendi (2016) sebagai berikut:

$$
\mathrm{BEP}_{\mathrm{vp}}=\frac{\text { Biaya Total }(\mathrm{Rp})}{\text { Harga }(\mathrm{Rp} / \mathrm{kg})}
$$

\section{b. BEP Harga}

BEP harga merupakan BEP yang menunjukkan harga jual minimal yang diterima petani agar tidak mengalami 
kerugian dengan rumus menurut Efendi (2016) sebagai berikut:

$$
B E P_{\text {Harga }}=\frac{\text { Biaya Total }(R p)}{\text { Produksi }(k g)}
$$

\section{HASIL DAN PEMBAHASAN}

\section{Karakteristik Responden}

Karakteristik responden meliputi umur, pengalaman, pendidikan, jumlah tanggungan keluarga, dan luas lahan (Tabel 1).

\section{Tabel 1. Karakteristik Responden}

\begin{tabular}{|c|c|c|c|}
\hline No & Uraian & Jumlah (orang) & Persentase (\%) \\
\hline \multirow[t]{3}{*}{1} & Umur Responden (Tahun) & & \\
\hline & $15-64$ & 21 & 100,00 \\
\hline & Jumlah & 21 & 100,00 \\
\hline \multirow[t]{5}{*}{2} & Pengalaman Bertani (Tahun) & & \\
\hline & a. $1-10$ & 11 & 53,38 \\
\hline & b. $11-20$ & 9 & 42,86 \\
\hline & c. $21-30$ & 1 & 4,76 \\
\hline & Jumlah & 21 & 100,00 \\
\hline \multirow[t]{4}{*}{3} & Tingkat Pendidikan & & \\
\hline & a. Tamat SD/sederajat & 18 & 85,71 \\
\hline & b. Tamat SMP/sederajat & 3 & 14,29 \\
\hline & Jumlah & 21 & 100,00 \\
\hline \multirow[t]{4}{*}{4} & Jumlah Tanggungan Keluarga (Orang) & & \\
\hline & a. $1-3$ & 10 & 47,62 \\
\hline & b. $4-6$ & 11 & 52,38 \\
\hline & Jumlah & 21 & 100,00 \\
\hline \multirow[t]{5}{*}{5} & Luas Lahan Garapan Tomat (Ha) & & \\
\hline & a. $<0,25$ & 3 & 14,29 \\
\hline & b. $0,25-0,50$ & 14 & 66,67 \\
\hline & c. $>0,50$ & 4 & 19,04 \\
\hline & Jumlah & 21 & 100 \\
\hline
\end{tabular}

Sumber: Analisis Data Primer, 2020

Tabel 1 menunjukkan bahwa seluruh responden termasuk dalam kelompok usia produktif (15-64 tahun). Menurut Anwar dan Fatmawati (2018), penduduk usia produktif adalah penduduk yang berumur 15-64 tahun. Menurut Talumingan dkk (2011), umur petani berpengaruh terhadap produktivitas kerja dan kemampuan petani dalam bekerja.

Sebagian besar responden memiliki pengalaman yang cukup dalam melaksanakan usahatani tomat, yaitu 1-10 tahun sebanyak 11 orang $(53,38 \%)$ dan 11 20 tahun sebanyak 9 orang $(42,86 \%)$. Menurut Manyamsari dan Mujiburrahmad 
(2014), pengalaman berusahatani memegang peranan penting dalam peningkatan kompetensi petani.

Sebagian besar responden memiliki tingkat pendidikan setingkat Sekolah Dasar (SD) yaitu sebanyak 18 orang atau $(85,71 \%)$ yang menunjukkan rendahnya tingkat pendidikan dari responden. Menurut Manyamsari dan Mujiburrahmad (2014), pendidikan menunjukkan tingkat kemampuan dan pemahaman petani mengenai segala sesuatu, baik peningkatan pengetahuan, keterampilan, dan perubahan sikap petani.

Responden yang memiliki jumlah tanggungan keluarga 1-3 orang sebanyak 10 petani $(47,62 \%)$, dan yang memiliki jumlah tanggungan keluarga 3-6 orang sebanyak 11 petani (52,38\%). Menurut Drakel (2011), jumlah tanggungan keluarga akan mempengaruhi tingkat produksi dan pendapatan. Menurut Norfahmi dkk (2017), selain sebagai produsen dan konsumen, rumah tangga petani juga berperan penting sebagai penyedia tenaga kerja. Menurut Suratman (2015), ketersediaan tenaga kerja dalam keluarga merupakan potensi yng cukup besar dalam kegiatan usahatani,

Sebagian besar responden memiliki lahan seluas $0,25-0,50$ ha yang termasuk kategori sedang menurut Suratiyah (2006).
Menurut Permadi dkk (2016), lahan adalah salah satu faktor produksi yang sangat penting dalam menentukan produksi usahatani yang diusahakan oleh petani.

\section{Analisis Titik Impas}

BEP penerimaan, volume produksi dan harga jual dapat dilihat pada Tabel 2.

Tabel 2. Titik Impas Usahatani Tomat

\begin{tabular}{|c|c|c|}
\hline No. & Uraian & Jumlah \\
\hline 1 & Biaya tetap & Rp 566.977,73/ha \\
\hline 2 & Biaya variabel & Rp $16.882 .350,59 / \mathrm{ha}$ \\
\hline 3 & Biaya total & Rp 17.449.328,32/ha \\
\hline 4 & Produksi & $21.125,15 \mathrm{~kg} / \mathrm{ha}$ \\
\hline 5 & Harga jual & $\mathrm{Rp} 2.000 / \mathrm{kg}$ \\
\hline 6 & Penerimaan & $\operatorname{Rp} 42.250 .295,16 / \mathrm{ha}$ \\
\hline 7 & Pendapatan & $\operatorname{Rp} 24.800 .966,84 / \mathrm{ha}$ \\
\hline 8 & BEP penerimaan & Rp 965.888,82/ha \\
\hline 9 & BEP volume produksi & $8.724,66 \mathrm{~kg}$ \\
\hline 10 & BEP harga & $\mathrm{Rp} 826 / \mathrm{kg}$ \\
\hline
\end{tabular}

Sumber: Analisis Data Primer, 2020

Tabel 2 menunjukkan bahwa penerimaan minimum yang harus diterima petani agar tidak mengalami kerugian sebesar Rp 965.888,82/ha. Produksi minimal dari usahatani tomat agar mencapai titik impas sebanyak 3.440,87 $\mathrm{kg} / \mathrm{ha}$. Harga jual minimal yang diterima petani tomat sebesar Rp 826/kg agar dapat mencapai titik impas.

Hasil penelitian Efendi (2016) pada usahatani tomat di Desa Mandesan Kecamatan Selopuro Kabupaten Blitar menunjukkan BEP volume produksi $10.819 \mathrm{~kg}$ dan BEP harga penjualan Rp 2.734. Penelitian Utami 
menunjukkan BEP rupiah sebesar Rp2.210.828, dan BEP unit sebesar 443 kg. Penelitian Ma'ruf dkk (2019) menunjukkan BEP produksi $358 \mathrm{~kg}$, dan BEP harga Rp 1.152/kg.

Analisis Titik Impas adalah alat analisis untuk membantu memahami hubungan timbal balik antara biaya, volume dan laba dalam organisasi dengan memfokuskan interaksi antar lima elemen yaitu harga pokok, volume/tingkat aktivitas, biaya variabel per unit, total biaya tetap dan bauran produk yang dijual. Kurva titik impas berdasarkan perhitungan titik impas penerimaan dan volume produksi dapat dilihat pada Gambar 1 .

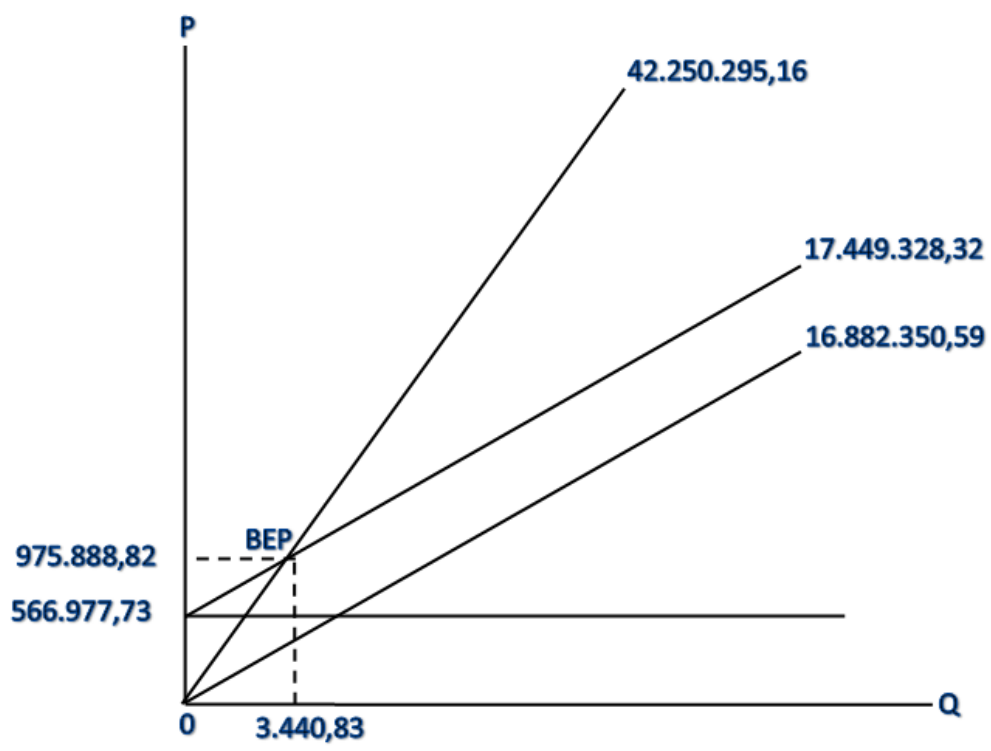

Gambar 1. Titik Impas Usahatani Tomat di Desa Sindangjaya Kecamatan Mangunjaya Kabupaten Pangandaran

\section{KESIMPULAN DAN SARAN}

\section{Kesimpulan}

BEP penerimaan $\mathrm{Rp} 965.888,82 / \mathrm{ha}$, BEP volume produksi 3.440,87 kg/ha, dan BEP harga Rp 826/kg.

\section{Saran}

Penurunan biaya produksi dan peningkatan produksi dapat meningkat-kan pendapatan petani.

\section{DAFTAR PUSTAKA}

Anwar, K. dan Fatmawati. 2018. Pengaruh Jumlah Penduduk Usia Produktif, Kemiskinan dan Inflasi Terhadap Pertumbuhan Ekonomi di Kabupaten Bireuen. Jurnal Ekonomi Regional Unimal, 1(1): 15-22.

Arikunto, S. 2013. Prosedur Penelitian Suatu Pendekatan Praktik. Jakarta: Rineka Cipta. Jakarta.

Badan Pusat Statistik Kabupaten Ciamis. 2019. Ciamis Dalam Angka 2019. Ciamis. 
Drakel, A. 2011. Kajian Usahatani Tanaman Tomat Terhadap Produksi dan Pendapatan Petani (Studi Kasus di Desa Golago Kusuma, Kecamatan Jailolo Timur, Kabupaten Halmahera Barat).Jurnal Ilmiah agribisnis dan Perikanan (agrikan UMMUTernate), 4(2): 31-36.

Efendi, Y. 2016. Analisis Usahatani Tomat (Lycopersicone esculentum Mill) di Desa Mandesan Kecamatan Selopuro Kabupaten Blitar. Jurnal Viabel Pertanian, 10(2): 51-61.

Manyamsari, I. dan Mujiburrahmad. 2014. Karakteristik Petani dan Hubungannya dengan Kompetensi Petani Lahan Sempit (Kasus: di Desa Sinar Sari Kecamatan Dramaga Kabupaten Bogor Jawa Barat). Agrisep, 15(2): 58-74.

Norfahmi, F., Kusnadi, N., Nurmalina, R. dan Winandi, R. 2017. Analisis Curahan Kerja Rumah Tangga Petani Pada Usahatani Padi dan Dampaknya Terhadap Pendapatan Keluarga. Informatika Pertanian, 26(1): 13-22.

Saeri, M. 2011. Usahatani dan Analisisnya. Malang: IKAPI.
Sugiyono. 2014. Metode Penelitian Kuantitatif, Kualitatif, dan $R \& D$. Bandung: CV Alfabeta.

Suratman, Y.Y.A. 2015. Kontribusi Tenaga Kerja dalam Keluarga Terhadap Pendapatan Usahatani Terong (Solanum melongena L.) di Kelurahan Landasan Ulin Utara Kecamatan Liang Anggang Kota Banjarbaru. ZIRAA'AH, 40(3): 218225.

Sutarni, Fitriani dan Unteawati, B. 2016. Analisis Rugi Laba Jangka Pendek Usaha Agribisnis Perikanan Air Tawar Kolam Khusus Ikan Patin di Kabupaten Lampung Tengah. Prosiding Seminar Nasional Pengembangan Teknologi Pertanian. Politeknik Negeri Lampung. Lampung. Hal. 315-316.

Talumingan, C., Kaunang, R. dan Habaludin, R. 2011. Analisis Pendapatan Usahatani Tomat di Desa Tonsewer Kecamatan Tompaso Kabupaten Minahasa. ASE, 7(3): 4351.

Utami, R. 2018. Analisis Usahatani Mitra Tani Tomat PT Xxxx Kabupaten Bogor. Jurnal Argobisnis, 7(3) : 1-8. 